\title{
Oncology
}

Arai, T. 46

Arber, N. 33

Aung, P.P. 17

Backlund, M.G. 28

Budhu, A.S. 23

DuBois, R.N. 28

Forgues, M. 23

Furuhata, T. 41

Hirata, K. 41

Jinno, K. 38

Kaminishi, M. 1

Kanazawa, K. 46

Katsuramaki, T. 41

Kimura, Y. 41

Kishi, K. 46

Kuniyasu, H. 17

Mann, J.R. 28

Masuda, M. 38

Mitani, Y. 17

Mizuguchi, T. 41

Mou, X.Y. 38

Murakoshi, M. 38

Nakayama, H. 17
Negishi, S. 46

Neid, M. 14

Nishikawa, N. 41

Nishimori, H. 41

Nishino, H. 38

Nobuoka, T. 41

Ohsaka, Y. 38

Okita, K. 41

Oue, N. 17

Samoha, S. 33

Satoh, M. 41

Satomi, Y. 38

Sawabe, M. 46

Schier, S. 9

Sun, Z. 23

Wada, S. 38

Wang, X.W. 23

Wittekind, C. 14

Wright, N. 9

Yasui, W. 17

Ye, Q.-H. 23

Zenbutsu, H. 41

Zipser, B. 23

\section{Subject Index Vol. 69, Suppl. 1, 2005}

Adenoma-carcinoma sequence 9 Adenomas 33

Age 46

Angiogenesis 14

Autopsy 46

Biliary tract malignancy 41

Calorie intake 46

Cancer 14

Carcinogenesis, gastric 1

Chemoprevention, cancer 1, 33, 38

Chronological trend 46

Colorectal adenoma 46

- cancer 28, 33, 46

Cyclooxygenase-2 28, 33

De novo cancer 46

Diversity, gastric carcinogenesis 1

Extracellular matrix 14

Functional foods 38

Gastric cancer 1, 17

Gastrointestinal cancer 9

Gene expression, serial analysis 17
GW112 gene 17

Hepatocellular carcinoma 23

HMGB1/amphoterin 17

15-Hydroxyprostaglandin dehydrogenase 28

Inflammation 1

Invasion 14

Liver cancer 23

Metastasis 14

$M I A$ gene 17

Molecular profiling, metastases 23

Multicarotenoids 38

Oesteopontin 23

Pancreaticobiliary maljunction 41

Pathogenesis 46

Phytochemicals, cancer prevention 38

Polyps 33

Prognosis, hepatocellular carcinoma 23

Prostaglandin $\mathrm{E}_{2} 28$

Stem cell relationships, gastrointestinal cancer origin 9 